\title{
Local Tourism? Why Not! Integrating Tourism Geographic Spatial in Ngawi Regency, Indonesia
}

\author{
Dyah E Setyowati ${ }^{1}$, Yani Antariksa ${ }^{1}$, Endri Haryati ${ }^{1}$, Haryono ${ }^{2}$ \& Indra P P Salmon ${ }^{3}$ \\ ${ }^{1}$ Department of Science Management, Sekolah Tinggi Ilmu Ekonomi Bisnis Indonesia, Jakarta, Indonesia \\ ${ }^{2}$ Department of Economic Development, Faculty of Economics and Business, University of Bhayangkara, \\ Surabaya, Indonesia \\ ${ }^{3}$ Department of Public Administration, Faculty of Social and Political Science, University of Bhayangkara, \\ Surabaya, Indonesia \\ Correspondence: Indra P P Salmon, Department of Public Administration, Faculty of Social and Political Science, \\ University of Bhayangkara, Indonesia.
}

Received: February 28, 2020

Accepted: August 24, 2020

Online Published: August 27, 2020

doi:10.5539/mas.v14n9p1

URL: https://doi.org/10.5539/mas.v14n9p1

\begin{abstract}
Ngawi Regency has a diversity of tourist destinations supported by the accessibility of strategic areas, but there are problems in the form of tourist visits opportunity that are still not optimal. The strategy that must be carried out is to design a tourist destination design in a strategic access corridor between the Special Region of Yogyakarta (DIY), Solo, Ngawi, and Surabaya (Yogya-Solo-Ngawi-Surabaya) and open access to local tourism information. This strategy is also applied on the basis of the strategic accessibility of Ngawi Regency which is located between the northern coast lines that connect various tourist attractions. The purpose of this study is to map each area of tourist destinations and connectivity within an integrated area, and; designing a spatial structuring model for integrated tourist destination areas in Ngawi Regency. The series is arranged in the corridor of tourist paths in Yogya-Solo-Ngawi-Surabaya. The method used in the study is a qualitative approach. Data collection is done through observation, in-depth interviews, descriptive statistical data, and documentation. The study results show that there are opportunities in the form of 9 development tourism destinations to be integrated in the Yogya-Solo-Ngawi-Surabaya tourism corridor. Integration is carried out in the tourist destination system in the districts: Karang Jati, Padas, Ngawi, Widodaren, Mantingan (Jatipangawitan). While in the spatial development policy of the Jogya-Solo-Ngawi-Surabaya corridor tourist area, components of tourism products are offered consisting of cultural attractions ( 3 main dances), accessibility (facilities and infrastructure), amenities (culinary, hotel, souvenirs), and activities (5 tour packages) that are developed according to the demand and dynamics of tourism in Indonesia.
\end{abstract}

Keywords: local tourism, spatial, Ngawi Regency, Indonesia

\section{Introduction}

Although supported by strategic accessibility and very high opportunities, the popularity of the tourism sector in Ngawi is still low considering that tourists who come from areas around Ngawi Regency only. Yet when looking at the opportunities available, tourism is an important resource and is able to have a positive impact on owners and managers (Liu \& Song, 2017; Paramati et al., 2017). Only the Trinil Museum is listed under the auspices of the government which until now has been preserved as a cultural tourism and historical site. The main problem is the high development opportunities for local tourism in Ngawi in the form of natural tourism, cultural tourism, and historical tourism separately visited, but constrained by the lack of access to information on the existence of tourism and weak development commitment so that the impact on the regional economy has not been optimal (Dianawati \& Nugrahani, 2020; Sharpley, 2010).

As a border area between provinces, Ngawi Regency has quite high accessibility. The accessibility is in the form of the density of land transportation traffic lanes (buses and trains) as well as the main route crossing the East Java region to Central Java and Yogyakarta Special Region (DIY). Tourism areas will be difficult to develop without the availability of transportation, considering the transportation system accessibility of the transportation system has a high correlation with efforts to develop tourism (Wang \& Chen, 2011; Wang et al., 2017). Apart from being 
a pathway between provinces in Java (between Central Java and East Java), it is also a tourist access point that uses a land access point from East Java to the tourist areas in DIY. For land routes alone, the 2017 projection figures show that as many as $65 \%$ of tourists use land routes such as trains, buses and private vehicles (DIY Tourism Province Department, 2019). If there are 765,065 tourists from East Java, then there are approximately 497,292 tourists going to DIY who use the land route and pass through Ngawi Regency. This figure is quite large and very likely considering the entire number of tourists from East Java not only from around the Regency of Ngawi, but more than that.

Table 1. The Number of Domestic Tourist from East Java to DIY (Through Ngawi Regency)

\begin{tabular}{|c|c|c|c|c|c|}
\hline \multirow{2}{*}{$\begin{array}{l}\text { Total Amount of Domestic } \\
\text { Tourist in DIY }(100 \%)\end{array}$} & $\begin{array}{l}\text { Domestic } \\
\text { (Accomn }\end{array}$ & $\begin{array}{c}\text { Tourist } \\
\text { dation Dat }\end{array}$ & $\begin{array}{l}\text { from } \\
\text { a) }\end{array}$ & Java & \multirow{2}{*}{$\begin{array}{l}\text { Total Amount of East } \\
\text { Java Domestic tourists } \\
(\mathbf{1 4 , 5 \% )}\end{array}$} \\
\hline & $\begin{array}{l}\text { Starred } \\
(10,2 \%)\end{array}$ & Hotel & \multicolumn{2}{|c|}{$\begin{array}{l}\text { Non-Starred Hotel } \\
(4,3 \%)\end{array}$} & \\
\hline $5,272,719$ tourists & $\begin{array}{l}538,145 \\
\text { tourists }\end{array}$ & domestic & $\begin{array}{l}226,920 \\
\text { tourists }\end{array}$ & mestic & 765,065 domestic tourists \\
\hline
\end{tabular}

Note. DIY Tourism Statistic 2018 Report (accessed 2020), modified by author. Copyright 2020 by Dinas Pariwisata DIY. Reproduce with permission.

The direction of development of tourism potential (in terms of products, markets, spatial geography, human resources, management, etc.) is needed so that it can foster positive and sustainable development for regional development and community welfare (Buckley et al. 2019; Hankhampa et al., 2011; Arnegger et al., 2010). The development of natural tourism and cultural heritage sites for example, experience shows that this effort has a very significant contribution to the economy of local and rural communities in many countries (Lai et al., 2017; Salvatore et al., 2018). For this reason, strengthening the role of each relevant stakeholder is needed (across sectors, across actors, across regions-regions) in order to encourage the development of tourism in a synergistic and integrated manner (Jones et al., 2011; Thongphon et al., 2013). The success rate of tourism in Ngawi Regency can be quickly realized if it is able to optimize the connectivity of Yogyakarta, Solo, Ngawi and Surabaya tourism destinations (the Yogya-Solo-Ngawi-Surabaya corridor) by forming a network of tourist attractions in the form of a package of attractions and tourist visiting patterns.

The suitability of the theme of tourist attraction, support of accessibility networks, having infrastructure that supports the movement of tourists, having integration with related sector plans that support strengthening competitiveness (Zahra, 2011; Okazaki, 2008). Creating a tourist destination in the Jogya-Solo-Ngawi-Surabaya corridor so that it can run as planned based on the superiority of tourism geography given the strategic tourism destination's location has the power to attract tourists from two regions to visit various tourist attractions (Wray, 2009; Gibson, 2008). This certainly also has opportunities related to spatial mapping in Ngawi Regency.

\subsection{Literature Review: Spatial Mapping of Tourism Objects and the Urgency of Tourist Corridor Model}

The choice of location for tourism spatial development activities must be considered appropriately. It is intended that these activities can take place productively and efficiently given the economic nodes play an important role in the effort to develop the region. Decisions of the region determined cause the emergence and development of the region (Tarigan, 2004). In other words, the mapping must consider whether or not the strategic location of tourism points with the density of potential tourists. Previously it was mentioned that one of the important considerations was the factor of the strategic lane area in Ngawi Regency, which was passed by land transportation and prospective tourist opportunities. For the tourism industry, land transportation is an important component in accommodating tourist destinations with tourists and has a significant impact on the development of tourist areas (Roselyne, 2008; Wang et al., 2012; Truong \& Shimizu, 2017).

Development planning brings various aspects of change when implemented in a planned and coordinated manner. The focus of spatial planning is the achievement of territorial subsystem goals that are organized territorially, as well as new approaches that integrate location, distance and environment (Hall \& Page, 2009). Spatial planning is also an important part in developing a geographic approach to tourist areas, especially in the aspect of impact, so it must also look at the context of development policy (Kang et al., 2014; Lee et al., 2019). Spatial balance can occur if there is a maximum profit, production-consumption balance, and free in and out (Wibowo \& Soetriono, 2008). 
Spatial development policy models are developed in several countries, including Indonesia, specifically to answer development needs, by utilizing its asset base, by determining optimal forms of land and space requirements. Realizing sustainable development (Anuar et al., 2013), it is necessary to set criteria in policy and strategy implementation, namely: (1) management scale; (2) scale of regional position; (3) regionalization; (4) material worthiness and identity; (5) the concept of development, and; (6) forms of representation of functional integration relationships. All of these criteria can then be operationalized from the perspective of spatial development in tourism.

To ensure that tourism development can work in harmony, it is necessary to work towards harmony between the development of the tourism sector and regional development. (Lee et al., 2010). Preparation of regional development plans and policies that apply always considers the ability and potential and urgent problems faced, so that tourism development efforts that take place in each region are in accordance with the state of the region. (Bendavid-Val, 1991; Arsyad, 2009). Tourism management must pay attention to principles:

a) The development and development of tourism is based on local wisdom and special local sense that reflects the uniqueness of cultural heritage and the uniqueness of tourist attraction objects, and;

b) Preservation, protection, and improvement of the quality of resources that are the basis of the development of tourism areas, and the ability to develop tourist attractions that are rooted in the local cultural treasury, uniqueness and local environment (Monavari et al., 2013; Healey, 2004; Bramwell, 2011).

The formulation of a framework for implementing tourism policy must touch on four aspects, namely development and infrastructure development; marketing activities; increasing the quality of culture and the environment, and; human resource development. Increasing the spatial role to meet the needs of tourism development programs that are developed appropriately and appropriately, then the involvement of local community participation must be empowered, because community members are considered most aware of the potential and condition of the community, meaning applying participatory approaches and community empowerment (Salazar, 2012; Moscardo, 2011 ).

As for what can be done are: (1) Conduct a needs analysis to map the carrying capacity of various potentials that exist; (2) Developing community empowerment models and partnerships with University-Industry, (3) Developing local wisdom-based community learning models so that they have scientific literacy, technology and international language communication skills, (4) Developing learning media by utilizing local content, (5) Improving the quality of local production through training and workshops (6) Helping access to international publications through the creation of websites and sites on tourist attractions (7) Helping people access to optimal assistance from the level of the bureaucratic authorities (Chen et al., 2011).

Package tourism objects and attractions according to the form of touring tourism aims to meet the needs of tourists who stay for a while, on the contrary for tourists who want to stay longer packaged in the form of destination tourism. Packaging based on the concept of destination tourism can be considered in the attractions of Kuta Beach, Mount Bromo, and Senggigi Beach. This area is filled with facilities that hold tourists like hotels, restaurants, entertainment venues and the like. Structuring attractions and interesting tourist attractions that must be done is to determine the tourist objects and attractions as the core attractions and supporters. The distance between the core object and its supporters is close so that it can be visited in less than one day and the route is designed in a circle so that it can return to its original place of departure (Sunaryo, 2013).

Determination of location as a center for creative tourism development must pay attention to accommodation facilities, entertainment venues, souvenir shops, the distance to tourist attractions must not be too far, and the transportation fleet needs to be addressed in terms of quality, quality and service because these facilities that bring tourists to the object and tourist attractions to be visited. Package objects, tourist attractions and accommodation facilities as well as easy accessibility to tourist attractions. Facilities to facilitate access and mobility of tourists can be met by providing means of transportation either by land, air and sea. Accommodation facilities play an important role in creative tourism because tourists planning to stay for a long time will definitely require lodging facilities. In developing a good accommodation facility must meet the requirements of facilities, services, rates and location (Prasiasa, 2013). The strategy of developing creative tourism as a driver of the tourism sector can be done by increasing the role of tourism arts and culture; strengthen the presence of creative industry clusters; the development of the creative economy and the development of tourism to craftsmen. 


\section{Research Method}

This research focuses on the existence of local tourism in Ngawi Regency which is compared with the strategic accessibility opportunities and domestic tourists. Existing local tourism and strategic accessibility in Ngawi Regency as a crossing pathway are the main triggers in tourism development. Tourist attractions that are still not much explored along with its supporting aspects become an advantage for tourists who want other popular tourist destinations that cross the line from East Java Province to the Special Region of Yogyakarta (DIY) and Central Java.

As an effort to provide alternative new options, a descriptive quantitative analysis was carried out on the data of tourists using land routes to see opportunities for the number of tourists who could be optimized to visit Ngawi Regency. In addition, data explorations were also conducted on tourist desires for the existence of local tourism and spatial integration of local tourism, which allows tourists to enjoy longer tourist visits. The data is then compared with studies conducted with regard to the impact of the existence of land transportation routes with the existence of tourist destinations and the role of local tourism development for tourists, local communities, and government.

\section{Result}

\subsection{Connectivity between Tourism Objects in Ngawi}

Translating tourism policies drawn up into concrete plans consisting of: (a) evaluating the wealth of tourism, natural and cultural assets and their protection and preservation mechanisms; (b) identification and categorization of tourism products that have competitive and comparative advantages; (c) determine the terms and conditions of providing the required infrastructure and superstructure that will have an impact on tourism performance, and; (d) elaborating programs for financing in tourism activities, for the public and private sectors.

Obtaining a mapping of the interrelationships between integrated tourism objects, the step taken is confirmation by using two dimensions of the meaning of data recording, namely fidelity and structure. Fidelity implies the extent to which real evidence from the field can be presented through audio or video recording so that it has high fidelity. The structural dimension is done through in-depth interviews and observations carried out systematically and structured in a way to ensure the validity of the data by triangulation and the time required in data collection which is complemented by focus group discussions (Bungin, 2007). The results of the evaluation of the wealth of tourism assets that can be integrated as many as 9 potential tourist destinations of Ngawi regency which, geographically located at position $7^{\circ} 21^{\prime}-7^{\circ} 31^{\prime}$ ' South Latitude and $110^{\circ} 10^{\prime}-111^{\circ} 40^{\prime}$ East Longitude.

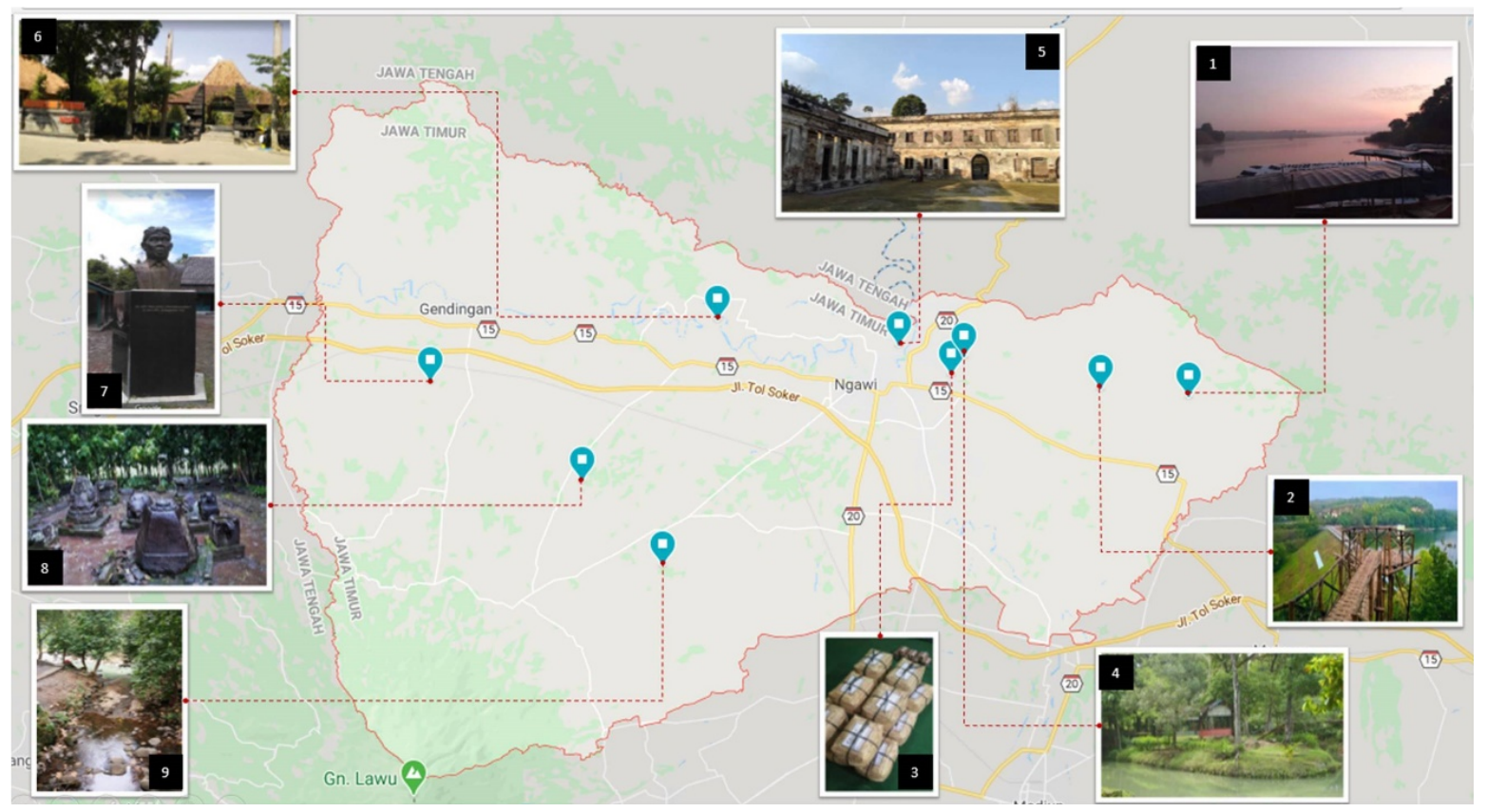

Figure 1. Mapping Corridor of Leading Tourist Destinations in Ngawi Regency (Jatipangawitan)

Note. The image is the result of a team design and accessed via Google Maps, modified by author. Copyright 2020 by Google. Reproduce with permission. 
Realizing sustainable, beautiful, enchanting, orderly, safe and comfortable tourism destinations carried out by structuring steps, enhancing supporting facilities and infrastructure, and developing tourist attractions, can be done through tourism destination development programs in realizing the Yogya-Solo-Ngawi-Surabaya corridor. Development of local tourism areas by strengthening tourism destinations in the Jatipangawitan Area because there are tourist objects in the Sub-District area: Karangjati, Padas, Ngawi, Widodaren, Mantingan. The path is a paved highway in Ngawi Regency, which stretches from the east from Caruban District (Madiun Regency) through Karang Jati District to splitting Ngawi City and to the west ends in Mantingan District, the border of East Java Province and Central Java Province with various types of objects, available tours as follows;

\subsubsection{Sangiran Reservoir}

Sangiran Reservoir is a water dam used for water storage, fishing, motorboat tours, rowing boats. This location is located in the northern part of Sumber Bening Hamlet, Bringin Regency. The road is paved, there is a gazebo and public transportation is not yet available. Many types of fish are found in the Sangiran reservoir, including Tilapia, Catfish, Tombro, Cork, Patin, and Milkfish. Sangiran Reservoir as an alternative to be used as water tourism, with additional safety facilities for visitors who rent a motorboat.

\subsubsection{Pondok Reservoir}

The location in Dero Village, Bringin sub-district $20 \mathrm{~km}$ east of Ngawi city, aside from being a means of irrigation and power generation, this dam is also used as a tourist attraction. In this Pondok Dam there are fishing areas, motorboats, camping grounds, playgrounds, paddles, sky water, photography and several dining spots for family recreation. Dam tourism object This lodge has an area of 2,596 hectares and is surrounded by mahogany forest and teak trees is very suitable for family tourism. The view is beautiful, the water is clear, the fish are abundant.

\subsubsection{Tempe Chips Production Center}

The process of tourism development arises as a follower industry that can be seeded as the main driving industry in the development of a region. The concentration of the tourism industry in one region will accelerate economic growth because it will create consumption patterns. The strength of the center of tourism development lies in the close interrelationships between several tourism industry activities because tourism activities are interrelated. Located $5 \mathrm{~km}$ east of the city of Ngawi, precisely in the village of Prandon, Ngawi sub-district, an estimated 600 home-based businesses carry out activities and snack businesses in the form of tempe chips. There are 18 types of flavors that have been developed, there are tempeh flakes, grilled chicken, soy sauce, onion chicken, salad seasoning, sweet corn, sweet spicy, and shrimp sauce.

\subsubsection{Tawun Pond}

The park is famous for its turtle habitats and water sources. Springs are used to supply swimming pool water and irrigate the surrounding rice fields. Every year, the surrounding community organizes traditional Keduk Beji ceremonies. Located in the village of Tawun, Padas sub-district a distance of $6 \mathrm{~km}$ east of the city of Ngawi has the potential to become a regional tourism asset that produces many benefits with a variety of tourist activities including swimming, water games, parks \& children's games. Real conditions around tourist destinations need to be developed simultaneously in the long run by cooperating with private parties/investors.

\subsubsection{Pendem Fort}

Van Den Bosch Fort or also called Pendem Fort which was built by the Dutch East Indies Government in 1839 -1845 under the name Van Den Bosch Fort, located in the meeting lane of Bengawan Solo and Bengawan Madiun, to face resistance or attacks by the Ngawi people whose government was centered in Ngawi Purba, led by Wirotani, a follower of Prince Diponegoro.

\subsubsection{Trinil Museum}

Museum of the storage of fossil monkey man walking upright Phitecantropus Erectus discovered by Dubois in 1881 - 1892. Located in Kawu Village, Kedunggalar District $13 \mathrm{~km}$ to the west of Ngawi city, this museum also keeps fossils of ancient bulls and elephants that are useful for archaeological history research. Resident's house adjacent to the entrance, can be cooperated as a place to sell souvenirs. Information on the price of admission to the Museum, should be given an information board.

\subsubsection{Heritage House Dr. KRT. Radjiman Wedyoningrat}

In this place still stands sturdy relic houses complete with furniture, household appliances and heirlooms are still stored and well maintained. Location $35 \mathrm{Km}$ from the west of the city of Ngawi is a type of historical tourism is often a place of ceremonies to commemorate the birth of Pancasila every June 1 by students. Real conditions 
include empowering the surrounding community by forming a Tourism Awareness Group as a substitute for tourism extension officers to the location does not exist.

\subsubsection{Bull Statue Site}

These ancient objects in the form of bull, phallus/yoni statues are a relic of the Majapahit Kingdom. These historical objects are located in the middle of residential areas and are managed by BP3 Trowulan under the supervision of the East Java Office of Tourism, Arts and Culture. As a historical tour of the Banteng statue, it is located in Reco Banteng Hamlet, Wonorejo Village, Kedunggalar District, $22 \mathrm{Km}$ west of Ngawi City. The real condition of the Bull Statue is very poor, environmental management is poorly organized, there is a need to increase security and there is no extension agent for tourism.

\subsubsection{Srigati's Couple Site}

Many people from Ngawi Regency and the surrounding area believe that in that location there is a crown (kuluk) from the legacy of King Brawijaya V. The belief of local residents, and all supernatural beings in the Ketonggo forest area. Certain days (Pon Friday and Legi Friday in Javas's Calendars) in the Javanese calendar Suro month, many pilgrims attend the annual Chang Langse ritual. As a spiritual tour, Pasanggrahan Srigati is $12 \mathrm{~km}$ to the southwest. The tourism object of Pasanggrahan Srigati needs adequate lighting, stalls need for equipment to carry out spiritual activities and temporary resting places need to be built.

\subsection{Designing Jogja-Solo-Ngawi-Surabaya Tourism Corridor Models}

According to Wahab (2012), a model is a reduced representation of an object or a condition that is intended to describe, explain, or discover the properties of its original form. The model is also interpreted as a simple representation of the selected aspects of the problem conditions that are arranged for specific purposes. One operational model consists of five stages of activity: (1) problem definition, (2) information gathering, (3) identification of alternative solutions to problems, (4) decision making and (5) implementation of actions.

Physical models are small reproduction of objects or physical objects. The abstract model is a simplification of certain policy phenomena or concepts expressed in the form of theoretical statements, symbols, images or mathematical formulations about the phenomenon they describe. Management of tourism areas is contained in one or more administrative areas that are equipped with tourist attraction objects, public facilities, tourism facilities, accessibility and the community that are interrelated or complementary. Realizing the Yogyakarta-Solo-Ngawi-Surabaya corridor offered components of tourism products consisting of attractions, accessibility, amenities and activities.

a) Attractions, which can be watched and presented consist of cultural arts attractions, and spiritual / spiritual ceremonial activities and events, including:

a. Orek-Orek Dance; is a traditional art in the form of social dance which is a combination of dance moves and singing accompanied by how to sound one of them, by "scraping".

b. The Keduk Beji Tradition; mud bathing rituals in Tawun Village, Kasreman District are carried out by cleaning the Sendang Tawun spring. Participants in the mud bath ritual consisted of children, teenagers, adults and the elderly.

c. Dongkrek Ngawi, is a Ngawi folk art, which is able to repel pageblugs or epidemics that interfere with the community, also to repel reinforcements, and reduce harm.

b) Amenity, is all supporting facilities that can facilitate tourism activities. Amenitas consist of accommodation, food and beverage, telecommunications, banking, souvenirs, security, clean water, electricity, health, tourism information center, guiding and interpretation. Other amenities can also be in the form of a viewpoint (point of view), places to eat, recreation and sports facilities, venues, markets and shops, parking facilities, and meeting facilities. At this time most of the components of the security are already available in the tourist area, although some others are still far from being feasible to provide excellent service to Jatipangawitan visitors / tourists in the sub-districts: Karang Jati, Padas, Ngawi, Widodaren, Mantingan.

c) Activities, are activities that can be carried out by tourists when visiting tourist destinations. The main tourism activities in the Jatipangawitan area are water tourism (Sangiran Reservoir and Pondok Reservoir); shopping tourism (tempe handicraft centers, teak knobs craftsmen, batik centers); historical tourism (Van De Bosch Fortress, Trinil Museum, Soerjo Monument, Rajiman W residence; cultural tourism (Pesanggrahan Srigati and Bull Statue):

a. Historical and Shopping Tour Packages with travel routes from Suryo Monument, Teak furniture craftsmen, Trinil Museum, Tempe chips center, Benteng Pendem. 
b. Nature, Shopping and History Tour Packages with Pondok Reservoir route, Batik Shopping, Pendem Fortress.

c. Ngawi City Tour Package with a route around the center of Ngawi city with the aim of shopping attractions batik, chips and Pendem Fortress.

d. Special Interest Package with objects for contemplation or pesanggahan Srigati, Benteng Pendem or Tawon Baths.

4) Accessibility, accesibility is the affordability of a tourist destination or a tourist attraction location both physically and socially. Accessibility concerns the ease of transportation for tourists to reach a tourist site but also the time required, and directions to tourist sites and other signs (signage) such as billboards so that the achievement of tourist attraction locations becomes easier, faster, and more convenient.

\section{Discussion: Local Tourism Chance and Opportunity in Ngawi Regency}

A survey of 22,000 respondents in 29 tourism markets in Indonesia, a trend that emerged in 2020 is the existence of a new tourist area. This trend emerged as an impact both socially, economically, and environmentally from the unwanted tourism overtourism by $54 \%$ of tourists (BUMN, 2020). Furthermore, the growth and development of popular tourist destinations, which have begun to have a negative impact on internal conditions, have begun to develop alternatives to new tourist destinations that balance social, economic and environmental aspects (Eom et al., 2020; Stylidis, 2017, Trang et al., 2019) . For this reason, in addition to aspects of the tourism component, an analysis of readiness around tourism destinations such as the community and managers is also needed, particularly in terms of social, economic and environmental aspects (Hunt \& Stronza, 2014; Nunkoo \& So, 2016). Tourists "second city", is a term for tourists lovers of tourist destinations that are already too full of visitors. As a consideration that tourist destinations that have overtourism are considered to have a bad environmental impact.

The growth of tourism which has an impact on the local community is also very popular. There are $60 \%$ of tourists wanting a recommendation for the new tourist destination (BUMN, 2020). For the management community, organization, or community around the tourist destination, the presence of "second city" tourists is one of the great opportunities. These opportunities are especially in improving the local economy and filling in the gaps in the growth of the tourism sector. This is obtained through the role of tourism as a means to supplement income, create employment, and increase taxes that come from tourist spending (Castro et al., 2013; Cardenas-Carcia \& Pulido-Fernandez, 2017; Cardenas-Garcia et al., 2015). in Indonesia and specifically Ngawi Regency, the majority of local tourism destinations are developed through collaboration between the government as a facilitator by empowering local communities and tourism awareness groups (pokdarwis) as businesses in the tourism sector. The effort was carried out as an effort to fill opportunities and significant contributions in the development of local areas so as to have an impact on improving local economic prosperity, community empowerment, environmental improvement efforts, and reducing poverty in the macro-level (Dodds et al., 2015; Lemelin et al., 2018; Manyara \& Jones, 2007; Tolkach \& King, 2015; Xu et al., 2018).

Satisfaction is the motivation of tourists visiting tourist destinations. It means that tourists want slow traveling and a package of tourist destinations must be provided with a little distance so that tourists have a longer time intensity at the location of the tourist attraction. The survey shows that $62 \%$ of tourists want the experience (BUMN, 2020). This consideration is influenced by psychological variables of tourists, environmental quality, demographics, experience and services obtained, or most importantly, spending on tourism (Wu et al., 2013; Kim et al., 2014; Middaugh et al., 2013; Aguiló \& Rossello, 2012 ). Thus, Ngawi Regency is one of the strong reasons for developing alternative tourism destinations. For local communities, there will be an increase in the economic side. Good accessibility (located between East Java and DIY), conducive environmental conditions are the basis of the feasibility of new tourist destinations.

The added value of this research is to provide recommendations in the form of practical implications for tourism development in Indonesia, especially in the border areas between East Java, Central Java, and the Special Region of Yogyakarta (DIY). DIY, which has become a popular tourism destination in Indonesia for both domestic and foreign tourists, needs to be refreshed by reducing the number of tourists. Domestic tourists who still need recreational activities can still enjoy entertainment facilities. Ngawi Regency which is in the border area (East Java, Central Java, and DIY) through the existence of the Jatipangawitan corridor map has the opportunity to become a second alternative city tourism with the impact of supporting a refresh in popular tourist areas such as DIY and increasing local income increase in the tourism sector in Ngawi Regency, East Java. 


\section{Conclussion}

Large and much tourism potential has not yet been developed on a regional scale through the development of the linkage of tourism objects as a unified system and is able to find the spatial development policy of the Ngawi Regency tourism area in realizing the Yogya-Solo-Ngawi-Surabaya corridor. The results of the identification there are 9 tourist attractions, including Sangiran Reservoir, Pondok Reservoir, Tempe Crush Center, Pasanggrahan Srigati, Tawun Baths, Van De Bosch Fortress, Trinil Museum, Bonggol Jati Craftsmen, Soerjo Monument, to the Bull Statue which can be developed to realize corridors Yogyakarta-Solo-Ngawi-Surabaya through the Ngawi regional tourism strategic development program. The policy carried out in the form of strengthening tourist attractions as a unified regional destination system in the districts: Karang Jati, Padas, Ngawi, Widodaren, Mantingan (Jatipangawitan) as a pivot highway in Ngawi Regency. The development of tourism in Ngawi Regency is developed through the formation of tourism interests including cultural tourism areas, natural tourism areas and artificial tourism areas. In realizing the Yogyakarta-Solo-Ngawi-Surabaya corridor offered components of tourism products consisting of attractions ( 3 main dances), accessibility (facilities and infrastructure), amenities (culinary, hotel, souvenirs) and activities (5 tour packages) which continue to be developed according to the demand of tourism actors.

\section{Acknowledgements}

o Director's of Research and Community Service Ministry of Research and Technology as a funding support institution on this research. Moreover to the partys that help on this research. A thank you to Ngawi Regency Government, c.q Village Leader, Village Officials and people of Majasem Village, Kendal, Ngawi on giving information and primary data and secondary data

Author would to say thanks to Ministry of Research and Technology as a funding support on this research; Ministry of Tourism and Economy Creative Republic of Indonesia, Ngawi Regency Governement, and University of Bhayangkara as a support institution on this researh.

\section{References}

Aguiló, E., \& Rossello, J. (2012). Research Note: The New All-Inclusive Board Formula in Mature Destinations-From Motivation to Satisfaction. Tourism Economics, 18(5), 1117-1123. https://doi.org/10.5367/te.2012.0151

Anuar, A. N. A., Ahmad, H., Jusoh, H., \& Hussain, M. Y. (2013). Policy and Tourism Development Strategy towards Tourist Friendly Destination in Kuala Lumpur. Asian Social Science, 9(2), 180-190. https://doi.org//10.5539/ass.v9n2p180

Arnegger,J., Woltering, M., \& Job, H. (2010). Toward A Product-Based Typology for Nature-Based Tourism: A Conceptual Framework. Journal of Sustainable Tourism, 18(7), 915-928. https://doi.org/10.1080/09669582.2010.485680

Arsyad, L. (2009). Ekonomi Pembangunan. Yogyakarta: STIE YKPN.

Bendavid-Val, A. (1991). Regional and Local Economic Analysis for Practitioners. New York: Preager Publishers.

Bramwell, B. (2011). Governance, The State and Sustainable Tourism: A Political Economy Approach. Journal of Sustainable Tourism, 19(4-5), 459-477. https://doi.org/10.1080/09669582.2011.576765

Buckley, R., Shekari, F., Mohammadi, Z., Azizi, F., \& Ziaee, M. (2019). World Heritage Tourism Triggers Urban-Rural Reverse Migration and Social Change. Journal of Travel Research, 00(0), 1-14. https://doi.org/10.1177/0047287519853048

Bungin, B. (2007). Data Penelitian Kualitatif. Jakarta: Rajawali Press.

Lee, C. F., Huang, H. I., \& Yeh, H. R. (2010). Developing An Evaluation Model for Destination Attractiveness: Sustainable Forest Recreation Tourism in Taiwan. Journal of Sustainable Tourism, 18(6), 811-828. https://doi.org/10.1080/09669581003690478

Cárdenas-García, P. J., \& Pulido-Fernández, J. I. (2017). Tourism as An Economic Development Tool: Key Factors. Current Issues in Tourism, 22(17), 2082-2108. https://doi.org/10.1080/13683500.2017.1420042

Cárdenas-García, P. J., Pulido-Fernández, J. I., \& Pulido-Fernández, M. C. (2015). The Influence of Tourist Satisfaction on Tourism Expenditure in Emerging Urban Cultural Destinations. Journal of Travel and Tourism Marketing, 33(4), 497-512. https://doi.org/10.1080/10548408.2015.1064061 
Castro, M., Molina, J. A., \& Pablo, M. P. (2013). Tourism and GDP: A Meta-analysis of Panel Data Studies. Journal of Travel Research, 52(6), 745-758. https://doi.org/10.1177/0047287513478500

Chen, C. M, Chen, S. H., \& Lee, H. T. (2011). The Destination Competitiveness of Kinmen's Tourism Industry: Exploring The Interrelationships Between Tourist Perceptions, Service Performance, Customer Satisfaction and Sustainable Tourism. Journal of Sustainable Tourism, 19(2), $247-264$. https://doi.org/10.1080/09669582.2010.517315

Dianawati, E., \& Nugrahani, R. U. (2020). Analysis of Tourism Marketing Communication Activities of Srambang Park Ngawi in Increasing Public Awareness. Global Research on Tourism Development and Advancement, 2 (1), 11-19.

Dodds, R., Ali, A., \& Galaski, K. (2018). Mobilizing Knowledge: Determining Key Elements for Success and Pitfalls in Developing Community-Based Tourism. Current Issues in Tourism, 21(13), 1547-1568. https://doi.org/10.1080/13683500.2016.1150257

Eom, T., Han, H., \& Song, H. (2020). Discovering The Perceived Attributes of CBT Destination Travelers in South Korea: A mixed method approach. Tourism Management, 77, 1-13. https://doi.org/10.1016/j.tourman.2019.104013

Hall, C. M., \& Page, S. J. (2009). Progress in Tourism Management: From The Geography of Tourism to Geographies of Tourism-A Review. Tourism Management, 30(1), 3-16. https://doi.org/10.1016/j.tourman.2008.05.014

Hankhampa, C., \& Chantachon, S. (2011). An Developing Alternative Tourism Potentials: A Path Following The National Co-developers on The Phu Phan Panges. Journal of Social Sciences, 7(2), 182-185. https://doi.org/10.3844/jssp.2011.182.185

Healey P. (2004). The Treatment of Space and Place in the New Strategic Spatial Planning in Europe. International Journal of Urban and Regional Research, 28(1), 45-67. https://doi.org/10.1111/j.0309-1317.2004.00502.x

Jones, T., Glasson, J., Wood, D., \& Fulton, E. A. (2011). Regional Planning and Resilient Futures: Destination Modelling and Tourism Development-The Case of The Ningaloo Coastal Region in Western Australia. Planning Practice and Research, 26(4), 393-415. https://doi.org/10.1080/02697459.2011.582377

Kang, S., Kim, J., \& Nicholls, S. (2014). National Tourism Policy and Spatial Patterns of Domestic Tourism in South Korea. Journal of Travel Research, 53(6), 791-804. https://doi.org/10.1177/0047287514522875

Kim, Y. H., Duncan, J. L., \& Jai, T. M. (2014). A Case Study of A Southern Food Festival: Using A Cluster Analysis Approach. Anatolia, 25(3), 457-473. https://doi.org/10.1080/13032917.2014.912245

Lai, P. H., Morrison-Saunders, A., \& Grimstad, S. (2017). Operating Small Tourism Firms in Rural Destination: A Social Representations Approach to Examining How Small Tourism Firms Cope with Non-Tourism Induced Changes. Tourism Management, 58, 164-174. https://doi.org/10.1016/j.tourman.2016.10.017

Lee, Y. J., Gray, L. P., \& Kim, J. (2019). Does Location Matter? Exploring The Spatial Patterns of Food Safety in $\begin{array}{lllll}\text { A Tourism } & \text { Destination. }\end{array}$ https://doi.org/10.1016/j.tourman.2018.09.016

Lemelin, R. H., Koster, R., \& Youroukos, N. (2015). Tangible and Intangible Indicators of Successful Aboriginal Tourism Initiatives: A Case Study of Two Successful Aboriginal Tourismlodges in Northern Canada. Tourism Management, 47, 318-328. https://doi.org/10.1016/j.tourman.2014.10.011

Liu, H., \& Song, H. (2017). New Evidence of Dynamic Links Between Tourism and Economic Growth Based on Mixed Frequency Granger Causality Tests. Journal of Travel Research, 57(7), 899-907. https://doi.org/10.1177/0047287517723531

Manyara, G., \& Jones, E. (2007). Community-Based Tourism Enterprises Development in Kenya: An exploration of Their Potential as Avenues of Poverty Reduction. Journal of Sustainable Tourism, 15(6), 628-644. https://doi.org/10.2167/jost723.0

Middaugh, J., Kwak, L. E., \& Meng, F. (2013). How Shopping Satisfaction Contributes to International Tourism Satisfaction and Tourism Expenditures by Gender: Analysis of US Tourists in South Korea. International Journal of Business Research, 13(1), 5-12. https://doi.org/10.18374/IJBR-13-1.1

Monavari, S. M., Khorasani, N., Mirsaeed, \& Seyedeh , S. G. (2013). Delphi-Based Strategic Planning for Tourism Management: A Case Study. Pol. J. Environ. Stud., 22(2), 465-473. 
Moscardo, G. (2011). Exploring Social Representations of Tourism Planning: Issues for Governance. Journal of Sustainable Tourism, 19(4-5), 423-436. https://doi.org/10.1080/09669582.2011.558625

Okazaki, E. (2008). A Community-Based Tourism Model: Its Conception and Use. Journal of Sustainable Tourism, 16(5), 511-529. https://doi.org/10.1080/09669580802159594

Prasiasa, D. P. O. (2013). Destinasi Pariwisata. Jakarta: Salemba Humanika.

Paramati, S. R., Alam, M. S., \& Chen, C. F. (2017). The Effect of Tourism on Economic Growth and CO2 Emission: A Comparison Between Developed and Developing Economies. Journal of Travel Research, 56(6), 712-724. https://doi.org/10.1177/00473287516667848

Roselyne, N. O. (2008). The Impact of Transportation on Tourism. Journal of Tourism, 9(2): 197-207.

Salazar, N. B. (2012). Community-Based Cultural Tourism: Issues, Threats and Opportunities. Journal of Sustainable Tourism, 20(1), 9-22. https://doi.org/10.1080/09669582.2011.596279

Salvatore, R., Chiodo, E., \& Fantini, E. (2018). Tourism Transition in Peripheral Rural Areas: Theories, Issues, and Strategies. Annals of Tourism Research, 68, 41-51. https://doi.org/10.1016/j.annals.2017.11.003

Sharpley, R. (2010). The Myth of Sustainable Tourism. CSD Working Paper, 4: 1-14.

Stylidis, D. (2017). Place Attachment, Perception of Place and Residents' Support for Tourism Development. Tourism Planning \& Development, 2(15), 188-210. https://doi.org/10.1080/21568316.2017.1318775

Sunaryo, B. (2013). Kebijakan Pembangunan Pariwisata. Yogyakarta: Gava Media.

Tarigan, R. (2004). Perencanaan Pembangunan Wilayah. Jakarta: Bumi Aksara.

Tolkach, D., \& King, B. (2015). Strengthening Community Based Tourism in A New Resource-based Island Nation: Why and How?. Tourism Management, 48, 386-398. https://doi.org/10.1016/j.tourman.2014.12.013

Tourism Department of The Special Province of Yogyakarta. (2019). Final Report on Tourist Shopping Analysis. Yogyakarta: Madani $\quad$ Callysta $\quad$ Saibuyun. $\quad$ Retrieved from https://visitingjogja.com/22902/laporan-akhir-analisis-belanja-wisatawan-2019/

Tourism Department of The Special Province of Yogyakarta. (2018). Tourism Statistic 2018. Yogyakarta: Tourism Department of The Special Province of Yogyakarta. Retrieved from https://visitingjogja.com/19962/statistik-pariwisata-diy-2018/

Thongphon, P. N. S., Naipinit, A., \& Patarapong, K. (2013). Sustainable Tourism Development and Management in the Phuket Province, Thailand. Asian Social Science, 9(7), 75-84. https://doi.org/10.55389/ass.v9n7p75

Trang, H. L. T., Lee, J., \& Han, H. (2019). How do Green Attributes Elicit Pro-environmental Behaviours in Guests? The Case of Green Hotels in Vietnam. Journal of Travel and Tourism Marketing, 36(1), 14-28. https://doi.org/10.1080/10548408.2018.1486782

Truong, N. V., \& Shimizu, T. (2017). The Effect of Transportation on Tourism Promotion: Literature Review on Application of The Coumputable General Equilibrium (CGE) Model. Transportation Research Procedia, 25 (2017), 3096-3115. https://doi.org/10.1016/j.trpro.2017.05.336

Wahab, S.A. (2012). Analisis Kebijakan: Dari Formulasi ke Penyusunan Model-Model Implementasi Kebijakan Publik. Jakarta: Bumi Aksara.

Wang, X., Huang, S., Zou, T., \& Yan, H. (2012). Effect of The High Speed Rail Network on China's Regional Tourism Development. Tourism Management Perspective, 1, 34-38. https://doi.org/10.1016/j.tmp.2011.10.001

Wang, D., Niu, Y., \& Qian, J. (2017). Evolution and Optimization of China's Urban Tourism Spatial Structure: A High Speed Rail Perspective. Tourism Management, 64(2018), 218-232. https://doi.org/10.1016/j.ytourman.2017.08.010

Wang, D., \& Chen, T. (2011). Spatial Analysis for Regional Difference on Tourism Economy in China. Scientia Geographica Sinica, 31(5), 528-536. https://doi.org/10.13249/j.cnki.sgs.2011.05.528

Wibowo, R., \& Soetriono. (2008). Konsep, Teori dan Landasan Analisis Wilayah. Malang : Bayumedi Publishing.

Wray, M. (2009). Policy Communities, Networks and Issue Cycles in Tourism Destination Systems. Journal of Sustainable Tourism, 17(6), 673-690. https://doi.org/10.1080/096695809030719789 
Wu, L., Zhang, J., \& Fujiwara, A. (2013). Tourism Participation and Expenditure Behaviour: Analysis Using A Scobit Based Discrete-Continuous Choice Model. Annals of Tourism Research, 40, 1-17. https://doi.org/10.1016/j.annals.2012.09.002

Xu, S., Kim, H. J., Liang, M., \& Ryu, K. (2018). Interrelationships Between Tourist Involvement, Tourist Experience, and Environmentally Responsible Behavior: A Case Study of Nansha Wetland Park, China. Journal of Travel \& Tourism Marketing, 35(7), 856-868. https://doi.org/10.1080/10548408.2018.1439429

Zahra, A. L. (2011). Rethinking Regional Tourism Governance: The Principle of Subsidiarity. Journal of Sustainable Tourism, 19(4-5), 535-552. https://doi.org/10.1080/09669582.2011.576764

\section{Copyrights}

Copyright for this article is retained by the author(s), with first publication rights granted to the journal.

This is an open-access article distributed under the terms and conditions of the Creative Commons Attribution license (http://creativecommons.org/licenses/by/3.0/). 